involvement should be considered when one examines young men with acne and arthritic symptoms.

\title{
References
}

1 Cros D, Gamby R, Serratrice G. Acne rheumatism. Report of a case. J Rheumatol 1981;8:336-339.

2 Rosner IA, Richter DE, Huettner TL et al. Spondylarthropathy associated with hydradenitis suppurativa and acne conglobata. Ann Intern Med 1982;97:520-525.

3 Lindroth Y, Hansen B, Holst R. Sakroiliit och missbruk av anabola steroider. Läkartidningen 1989;86:3369-3370.

4 McCarty DJ, Arthritis and allied conditions. Philadelphia: Lea and Febiger, 1985;820-821.

5 Järvholm U, Bergmann BR, Elgefors B. Bakteriell infektion i sakroiliakleden. Läkartidningen 1984;81:2278-2279.

6 Traupe H, von Muhlendahl KE, Brämswig J, Happie R. Acne of the fulminans type following testosterone therapy in three excessively tall boys. Arch Dermatol 1988;124:414-417.

7 Marynick SP, Chakmakjian ZH, McCaffree DL, Herndon JH. Androgen excess in cystic acne. N Engl J Med 1983;308:981-986.

8 Davis DE, Viozzi FJ, Miller OF, Blodgett RC. The musculoskeletal manifestations of acne fulminans. J Rheumatol 1981;8:317-320.

9 Williamson DM, Cunliff WJ, Gatecliff M, Scott DG. Acute ulcerative acne conglobata (acne fulminans) with erythema nodosum. Clin Exp Dermatol 1977;2:351-354.

10 Goldschmidt H, Leyden J. Stein K. Acne fulminans. Arch Dermatol 1977;113;444-449.

11 Edlund E. Johnsson U, Lidgren L et al. Palmoplantar pustulosis and sternoclavicular arthro-osteitis. Ann Rheum Dis 1988;47:809-815.

RSM 00037

\section{Frequency and causes of bucco-lingual-facial dyskinesias in the elderly}

\author{
D. Strubel, S. Bimboes, F. Kuntzmann and M. Berthel \\ Geriatric Department, Hôpital de la Robertsau, Strasbourg, France
}

Key words: Bucco-lingual-facial dyskinesia; Geriatrics; Neuroleptic drug

Bucco-linguo-facial dyskinesias (BLFD) are the most common form of movement disorder in the elderly; they may occur spontaneously, or be secondary to treatment with neuroleptic drugs (tardive dyskinesias). Although these dyskinesias are generally benign and well-tolerated, they can be serious and disabling.

Correspondence to: Dr D. Strubel, 264 rue de la République, 30320 Poulx, France. 0924-6479/90/\$03.50 @ 1990 Elsevier Science Publishers B.V. (Biomedical Division) 
Since there are few epidemiological data on this condition in the elderly, we undertook a study in 614 subjects (107 men and 507 women), all aged 70 or over, the average age being 83.9 years. The series comprised 126 hospitalized geriatric patients, 207 chronic invalids, 218 residents in retirement homes, and 63 patients from general practice. Neuroleptic treatment, generally using sedative drugs administered in low doses, had been used in $30.6 \%$ of all patients but in $41.1 \%$ of the chronic invalids; patients had not received anticholinergic drugs to counter extrapyramidal effects, but $23.3 \%$ of the entire group were taking benzodiazepines.

Careful clinical observation showed the presence of BLFD in $8.8 \%$ of cases, i.e. 54 patients ( 4 men and 50 women), though the disorder had in only a few cases been noted in the medical records. In the subgroups, the incidence of dyskinesia was 5.9\% among individuals in retirement homes, $6.3 \%$ in patients from general practice, $7.9 \%$ in hospitalized subjects and as high as $13 \%$ in chronic invalids. The condition was clearly more frequent in women $(9.9 \%)$ than in men $(3.3 \%)$, but within the age group studied there was no further relationship to increasing age. A history of recent neuroleptic treatment was slightly but not significantly more common in subjects suffering from BLFD than in others. On the other hand, treatment with benzodiazepines was significantly more common $(P<0.01)$ in non-dyskinetic subjects (23.3\%) than in dyskinetic subjects (16.7\%).

Of the 54 cases of BLFD, 20 could be considered as spontaneous and 34 as tardive dyskinesias in patients receiving neuroleptics. Most cases were mild, only one being classified as severe. Dental problems (edentation, poorly fitting prostheses) were equally common in neuroleptic and spontaneous cases. The patients with BLFD who were receiving neuroleptics were all classified as suffering from tardive dyskinesia, and there was no predominance of any particular type of neuroleptic.

This study confirms some of the trends evident from the literature [1-3], notably the high incidence of BLFD in the elderly and the role of certain risk factors (neuroleptic treatment even in low doses, dental problems). It indicates how commonly this type of dyskinesia may go unrecorded unless it is specifically looked for. Finally, our data point to some protective effect of benzodiazepines, an interesting finding in the light of current hypotheses as to the pathophysiology of tardive dyskinesias, which suggest a derangement of the GABA system.

\section{References}

1 Bourgeois M, Boueilh P, Tignol J. Dyskinésies spontanées séniles idiopathiques et dyskinésies tardives des neuroleptiques. Enquête chez 270 vieillards. Encephale 1980;6:37-40.

2 Kane JM, Smith JM. Tardive dyskinesia: prevalence and risk factors, 1959 to 1979. Arch Gen Psychiatr 1982;39:473-481.

3 Ramsay FM, Millard PH. Tardive dyskinesia in the elderly. Age Ageing 1986;15:145-150. 